\title{
Little Leaf Notcher (suggested common name) Artipus floridanus Horn (Insecta: Coleoptera: Curculionidae) ${ }^{1}$
}

\author{
Gabrielle LaTora and Adam G. Dale ${ }^{2}$
}

\section{Introduction}

Artipus floridanus Horn, known as the little leaf notcher, is a secondary pest of citrus in Florida and the Caribbean region (Figure 1). This beetle is in the family Curculionidae, the weevils and snout beetles. The little leaf notcher is one of several beetle species classified as citrus root weevils, along with the Diaprepes root weevil (Diaprepes abbreviatus), the blue-green citrus root weevil (Pachnaeus litus and Pachnaeus opalus), and the Fuller rose beetle (Asynonychus godmani) (Duncan et al. 2016).

Artipus floridanus has a wide host range, meaning it can feed on many different plants. In addition to citrus, Artipus floridanus can feed on a variety of crops, Florida native plants, and several exotic ornamentals (Duncan et al. 2016). Many of its hosts are commonly planted ornamentals in Florida landscapes.

\section{Distribution}

Artipus floridanus is native throughout central and southern Florida and in several Caribbean nations, including the Bahamas and the US Virgin Islands (Duncan et al. 2016; Rowan 1976). It is the only species in the genus Artipus found in the continental US, but its distribution is restricted to Florida (Woodruff 1985).

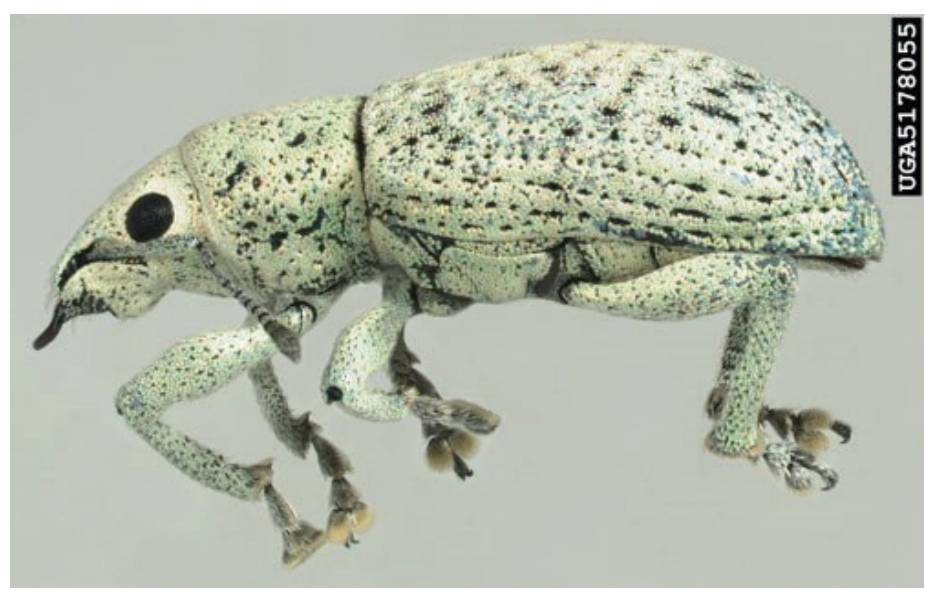

Figure 1. Adult little leaf notcher, Artipus floridanus Horn (lateral view). Credits: Natasha Wright, Cook's Pest Control, www.bugwood.org

\section{Description}

Artipus floridanus is described as 6.25 to $14 \mathrm{~mm}$ long and evenly whitish or bluish white, sometimes reflecting pale purple (Figures 1 and 2) (Hubbard 1885, Woodruff 1979). It tends to have longer and narrower elytra (hardened, protective forewings) than other citrus weevils (Woodruff 1979). Adults lack long hairs behind the eye that are present in other citrus weevils (Figure 3) (Woodruff 1979).

1. This document is EENY-740, one of a series of the Entomology and Nematology Department, UF/IFAS Extension. Original publication date September 2019. Visit the EDIS website at https://edis.ifas.ufl.edu for the currently supported version of this publication. This document is also available on the Featured Creatures website at http://entomology.ifas.ufl.edu/creatures.

2. Gabrielle LaTora; and Adam G. Dale, Entomology and Nematology Department; UF/IFAS Extension, Gainesville, FL 32611.

The Institute of Food and Agricultural Sciences (IFAS) is an Equal Opportunity Institution authorized to provide research, educational information and other services only to individuals and institutions that function with non-discrimination with respect to race, creed, color, religion, age, disability, sex, sexual orientation, marital status, national origin, political opinions or affiliations. For more information on obtaining other UF/IFAS Extension publications, contact your county's UF/IFAS Extension office. U.S. Department of Agriculture, UF/IFAS Extension Service, University of Florida, IFAS, Florida A \& M University Cooperative Extension Program, and Boards of County Commissioners Cooperating. Nick T. Place, dean for UF/IFAS Extension. 


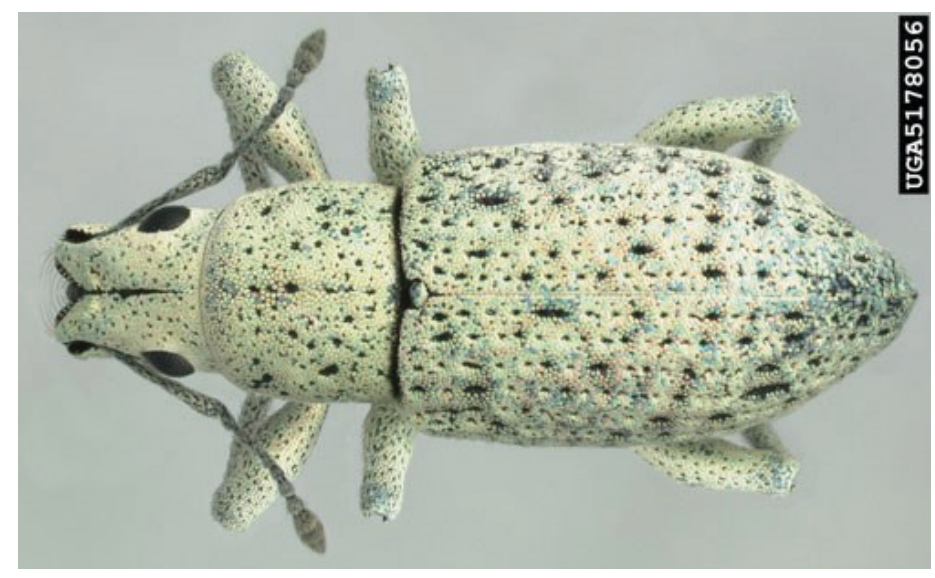

Figure 2. Adult little leaf notcher, Artipus floridanus Horn (dorsal view). Credits: Natasha Wright, Cook's Pest Control, www.bugwood.org
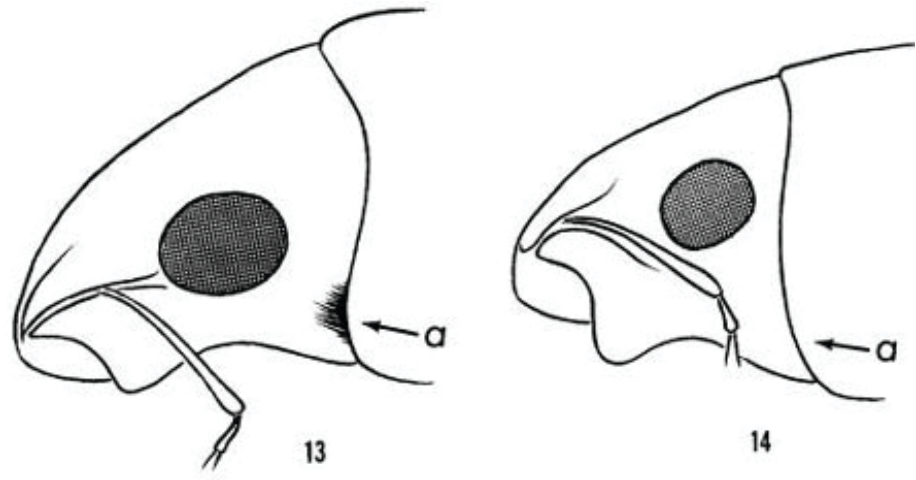

Figure 3. Illustration of hairs present behind eye of Tanymecus lacaenus Herbst (left) compared to Artipus floridanus Horn, which lacks hairs behind the eye (right).

Credits: Woodruff (1979)

\section{Biology}

\section{Eggs}

Adults feed, mate, and lay eggs on leaves, trunks, and stems of their host plant (Duncan et al. 2016). Eggs are whiteto-yellow, round, and hatch up to 20 days after oviposition into larvae, which drop to the ground and burrow into the soil to feed on plant roots (McCoy et al. 1985, Duncan et al. 2016).

\section{Larvae}

Artipus floridanus larvae are white grub-like insects with a darker, hardened head capsule. The larval stage comprises six instars, or stages of growth, and final instar larvae are about $9.5 \mathrm{~mm}$ long. Larvae develop underground, feeding on tree roots for approximately 45 days before they pupate or become dormant. The vast majority of larvae are concentrated within a $50 \mathrm{~cm}$ radius around the base of the trunk and 7.5 to $15 \mathrm{~cm}$ below the soil surface (Tarrant and McCoy 1985), which is the area containing most of the tree root mass.

\section{Pupae}

Larvae build small chambers in their excrement where they pupate for 14 to 20 days before emerging from the soil as adults (McCoy et al. 1985). Pupae do not feed.

\section{Adults}

The date of adult emergence depends in part on environmental factors like temperature and precipitation (Duncan et al. 2016). Adults cannot fly. They physically climb up the host trunk or stem to foliage, where they begin feeding on host foliage (Duncan et al. 2016). Adults can live for up to 165 days (McCoy et al. 1985). Similar to other weevils, males are significantly smaller than females, which is apparent when observing a mating pair (Figure 4).

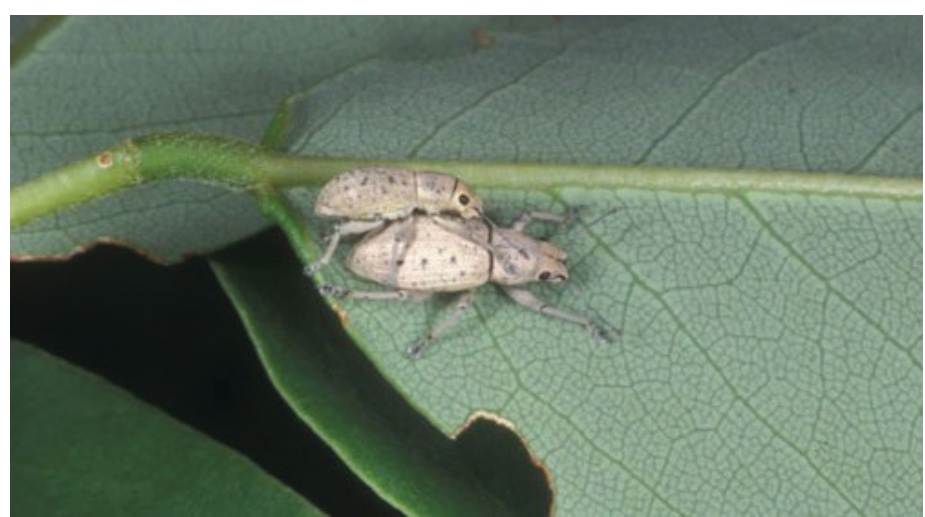

Figure 4. A mating pair of male and female adult little leaf notcher, Artipus floridanus Horn on vegetation, note notching on leaves. The smaller male is above the female.

Credits: Lyle J. Buss, UF/IFAS

Mated females will begin to lay eggs 11 to 20 days after emerging from pupae and can deposit approximately 1,220 eggs during their lifespans (McCoy et al. 1985). In a laboratory experiment by McCoy et al. (1985), over $80 \%$ of eggs laid by mated females survived to hatch. Females laid more egg masses in total darkness than in full daylight, suggesting they may perform this activity nocturnally in the field. In Florida, citrus growers observe the highest adult densities at three intervals during the year: April to May, June to July, and October to November (Duncan et al. 2016). Under laboratory conditions, Artipus floridanus can complete one full life cycle in 70 to 120 days and has several overlapping generations per year (McCoy et al. 1985;

Duncan et al. 2016).

\section{Host Plants}

The little leaf notcher was first described feeding on orange tree foliage in south Florida in 1879 (Hubbard 1885). Citrus species, including orange, grapefruit, and lime, are preferred hosts, but Artipus floridanus also feeds on at least 150 different plants (Woodruff 1982). Several of these non-crop 
hosts are important dune-building plants in coastal areas that are the foci of restoration regimes (Williams 2007). Artipus floridanus may threaten these fragile areas in some cases.

Crop hosts of the little leaf notcher include citrus (Citrus spp.), peanut (Arachis hypogaea), avocado (Persea americana), mango (Mangifera indica), lima bean (Phaseolus lunatus), Surinam cherry (Eugenia uniflora), and collards (Brassica oleraceae var. acephala), among others (Rowan 1979).

In Florida, native and exotic ornamental host plants include lantana (Lantana depressa), sea grape (Coccolobis uvifera), bottlebrush (Melaleuca spp.), rose (Rosa spp.), hibiscus (Hibiscus spp.), Australian pine (Casuarina spp.), azalea (Rhododendron spp.), and sea oats (Uniola paniculata), among others (Rowan 1979).

Their presence in citrus is widely noted, but they may be even more numerous on non-crop hosts. In commercial citrus field studies, Tarrant and McCoy (1985) collected eight times more larvae within herbaceous cover crops bordering the groves than from the orange trees themselves.

\section{Damage}

Citrus weevils as a group cause characteristic leaf injury. Adult Artipus floridanus feed along leaf edges, chewing 5 to $10 \mathrm{~mm}$ in from the leaf margin, then repositioning further along the leaf edge and repeating this behavior (Figure 5) (Rowan 1976). This activity results in small notches formed along leaf edges, hence the common name.

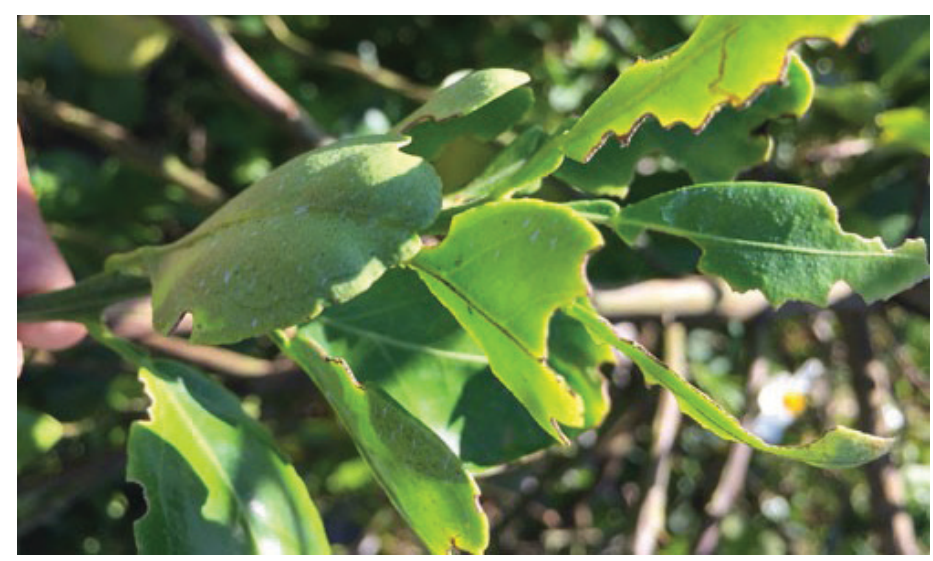

Figure 5. Leaf injury characteristic of adult citrus weevils. Credits: Jawwad Qureshi, UF/IFAS

Larvae are root feeders, so feeding injury often occurs without a visible cause (Rowan 1976). A similar citrus weevil pest, Diaprepes abbreviatus, also feed on roots as larvae, which predisposes the host citrus tree to Phytophthora spp. root rot pathogens. Although possible, there is no documentation of this pathogen's association with Artipus floridanus larval feeding. Artipus floridanus adults prioritize new growth over more mature vegetation when feeding on citrus and consume more vegetation under dark or dim light conditions (McCoy et al. 1985).

Both males and females contribute to leaf injury, but males feed less, probably because they require less energy for survival and reproduction compared to females (Syvertsen and McCoy 1985). Low population densities typical of commercial orange groves in spring and summer can destroy $4 \%$ of a tree's leaf area in three days (Syvertsen and McCoy 1985). The leaf area destroyed by feeding increases as the Artipus floridanus population increases (Syvertsen and McCoy 1985).

Injured leaves have reduced rates of $\mathrm{CO}_{2}$ assimilation, photosynthesis, and transpiration that are crucial to tree survival (Syvertsen and McCoy 1985). Low-density Artipus floridanus populations can reduce water use efficiency of leaves by up to $20 \%$ (Syvertsen and McCoy 1985).

\section{Economic Importance}

In 2018, Florida's citrus crop was valued at $\$ 551$ million, which is the largest citrus market of any US state (FDACS 2019). While other root weevils can be key pests of citrus, Artipus floridanus rarely poses a significant economic threat; however, many commercial citrus groves are already stressed by citrus greening disease, a significant pathogen in commercial orange production. Therefore, Artipus floridanus larvae feeding on infected roots can exacerbate tree stress and damage (Duncan et al. 2016). Because many citrus plantings in the state are infected with citrus greening disease, Artipus floridanus has the potential to cause additional economic losses.

Although season-long feeding can destroy up to $30 \%$ of an orange tree's foliage, mature stands of commercial orange trees are not as susceptible to feeding injury, likely because they have sufficient stored resources (Tarrant and McCoy 1985; Duncan et al. 2016). Therefore, mature trees rarely suffer economic damage (Duncan et al. 2016).

Feeding by Artipus floridanus may affect the aesthetic and economic value of ornamental plantings in Florida's urban and residential landscapes; however, this insect rarely calls for pest control action. 


\section{Management}

Because Artipus floridanus is rarely a primary threat to crop production, it may emerge as a secondary pest when predators are removed from the system. This can occur following application of broad-spectrum pesticides or during times when plants are vulnerable. Cultural, mechanical, biological, and chemical control strategies have been utilized for Artipus floridanus management.

Note: The following control activities should not be considered recommendations. Contact a pest management professional or your local UF/IFAS Extension office before implementing any of the following controls. Current UF/ IFAS Extension publications, like the Floria Citrus Production Guide, provide the most recent recommendations.

\section{8-2019 Florida Citrus Production Guide: Citrus Root Weevils}

Before implementing any control, accurate identification and monitoring is necessary. Larval populations cannot be monitored without physically unearthing trees, so the most effective monitoring focuses on adult populations (Duncan et al. 2016). This can be accomplished by scouting with the naked eye or with ground emergence traps placed under known hosts (Figure 6) (Duncan et al. 2016).

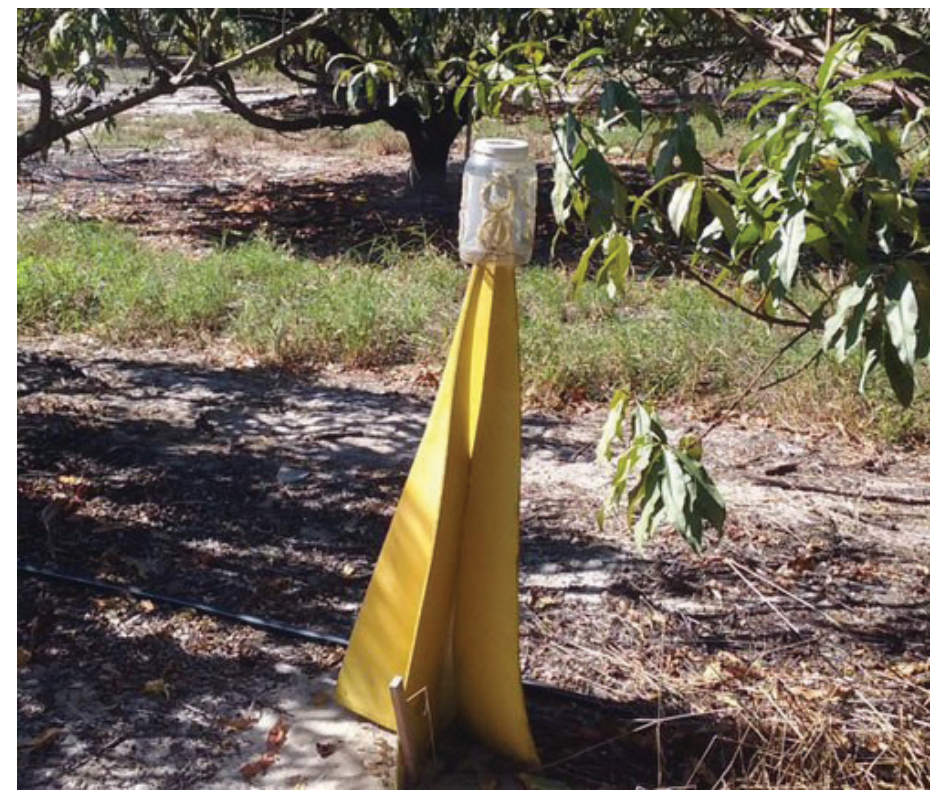

Figure 6. A ground emergence trap typical of those used for monitoring citrus weevil pests.

Credits: Brianna Whitman, UF/IFAS

Cultural control tactics include weed management beneath trees and other crops, removing known hosts from the area, and reducing plant stress by ensuring proper fertilization, irrigation, and drainage (Knapp 1985; Duncan et al. 2016). For citrus growers, the use of rootstocks that are resistant to other citrus weevil pests, like trifoliate orange and 'Swingle' citrumelo, may reduce root injury from Artipus floridanus larvae (Duncan et al. 2016).

Mechanical controls include removal of adult Artipus floridanus by hand and removal of infested vegetation by pruning when feasible and practical (Knapp 1985).

Biological control practices include the use of entomopathogenic nematodes, a tactic for other citrus root weevils (Bullock et al. 1999). Species used include Sterinernema carpocapsae (all strains), Steinernema riobravis, and Heterorhabditis bacteriophora (Florida and HP-88 strains), which all provide effective control of the Diaprepes root weevil (Schroeder 1992; Bullock et al. 1999). Nematodes are typically applied as soil treatments. Beauvaria bassiana, a commercially used entomopathogenic fungus, has been used to control little leaf notcher adults, although its efficacy in the field is variable (Beavers et al. 1983; Tarrant and McCoy 1985).

Two known parasitoids of little leaf notcher have been identified, Oestrophasia sabroskyi (Diptera: Tachinidae) (Kovarik and Reitz 2005) (Figure 7) and at least one wasp species in the genus, Micronotus (Hymenoptera: Braconidae) (Bullock 1984). These insects lay eggs on or inside little leaf notcher larvae, causing delayed but effective control. Both parasitoids are native to Florida and not commercially available. Habitats with diverse, native vegetation and greater structural complexity may provide resources and refuge for these valuable natural enemies, allowing them to survive and reproduce in the landscape.

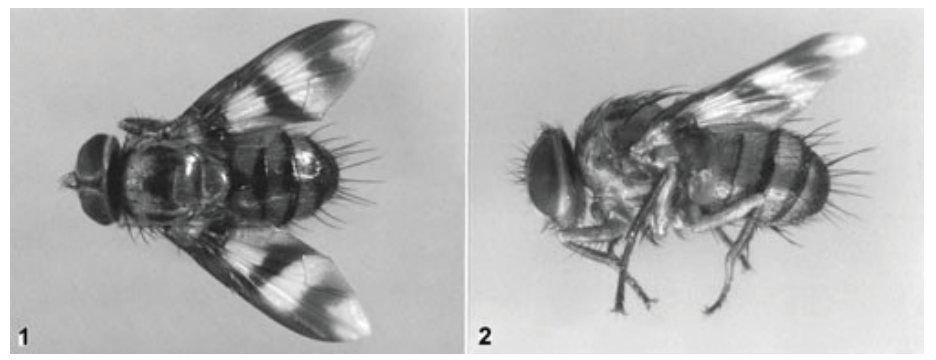

Figure 7. Adult Oestrophasia sabroskyi (Diptera: Tachinidae), a native parasitoid of adult Artipus floridanus Horn.

Credits: Kovarik and Reitz (2005)

Chemical controls like soil drenches and chemical barriers around the bases of trees have been used for larval control (Knapp 1985; Duncan et al. 2016). Foliar insecticide sprays have been used to control adults and destroy egg masses, although the chemical names and formulation recommendations have changed over time (Duncan et al. 2016). Insecticidal soaps and oils have been used to desiccate and, in some cases, physically remove adults and eggs (Knapp 1985). 
Insecticides should be applied following the implementation of cultural, mechanical, and biological controls. They can be applied preventively and rotated with commercially available biological control products, like entompathogenic nematodes, in areas where Artipus floridanus populations are already established. The extent of feeding damage, effectiveness of non-chemical control methods, and negative effects of various insecticides should be considered before their incorporation into a management regime for Artipus floridanus.

\section{Selected References}

Beavers J. B., McCoy C. W., and Kaplan D. T. 1983. "Natural enemies of subterranean Diaprepes abbreviatus (Coleoptera: Curculionidae) larvae in Florida." Environmental Entomology 12: 840-843.

Bullock R. C. 1984. "Endoparasitic braconid (Hymenoptera: Braconidae) attacks little leaf notcher Artipus floridanus (Coleoptera: Curculionidae) in Florida USA." Florida Entomologist 67: 571-572.

Bullock R. C., Pelosi R. R., and Killer E. E. 1999. "Management of citrus root weevils (Coleoptera: Curculionidae) on Florida citrus with soil-applied entomopathogenic nematodes (Nematoda: Rhabditida)." Florida Entomologist 82: 1-7.

Duncan L. W., Rogers M. E., Futch S. H., and Graham J. H. 2016. 2016 Florida citrus pest management guide: Citrus root weevils. ENY-611. Gainesville: University of Florida Institute of Food and Agricultural Sciences. https://edis.ifas. ufl.edu/cg006

Florida Department of Agricultural and Consumer Services (FDACS). 2019. Florida citrus statistics. https://www.nass. usda.gov/Statistics_by_State/Florida/Publications/Citrus/ Citrus_Statistics/2017-18/fcs1718.pdf (19 July 2019)

Hubbard H. G. 1885. Insects affecting the orange. U.S. Government Printing Office. Washington, D.C. 132-134.

Johnson E. G., Wu J., Bright D. B., and Graham J. H. 2014. "Association of 'Candidatus Liberibacter asiaticus' root infection, but not phloem plugging with root loss on huanglongbing-affected trees prior to appearance of foliar symptoms." Plant Pathology 63: 290-298.

Knapp J. L. 1985. “The citrus root weevils in Florida: An Extension service perspective." Florida Entomologist 68: 368-370.
Kovarik P. W., and Reitz S. R. 2005. "Oestrophasia (Cenosoma) sabroskyi (Diptera: Tachinidae), a parasitoid of Artipus floridanus (Coleoptera: Curculionidae): taxonomy and bionomics." Annals of the Entomological Society of America 98: 245-251.

McCoy C. W., Segretain C. M., Beavers G. M., and Tarrant C. A. 1985. "Laboratory rearing and some aspects of the biology of Artipus floridanus (Coleoptera: Curculionidae)." Florida Entomologist 68: 379-385.

Rowan W. T. 1976. "Florida host plants of Artipus fioridanus (Coleoptera: Curculionidae)." Florida Entomologist 59: 439-440.

Schroeder W. J. 1992. "Entomopathogenic nematodes for control of root weevils of citrus." Florida Entomologist 75: 563-567.

Syvertsen J. P., and McCoy C. W. 1985. "Leaf feeding injury to citrus by root weevil adults: Leaf area, photosynthesis, and water use efficiency." Florida Entomologist 68: 386-393.

Tarrant C. A., and McCoy C. W. 1985. "Sampling and distribution of Artipus floridanus (Coleoptera: Curculionidae) on citrus and weed hosts." Florida Entomologist 68: 393-398.

Williams M. J. 2007. Native plants for coastal restoration: What, when, and how for Florida. USDA, NRCS, Brooksville Plant Materials Center, Brooksville, FL. Accessed October 22, 2018. http://www.fl.nrcs.usda.gov/programs/ pmc/flplantmaterials.html

Woodruff R. E. 1979. "Florida citrus weevils (Coleoptera: Curculionidae)." Entomology Circular. Florida Department of Agriculture and Consumer Services, Division of Plant Industry 202: 1-4.

Woodruff R. E. 1982. “Artipus floridanus Horn: Another weevil pest of citrus.” Entomology Circular. Florida Department of Agriculture and Consumer Services, Division of Plant Industry 237: -2 .

Woodruff R. E. 1985. "Citrus weevils in Florida and the West Indies: Preliminary report on systematics, biology, and distribution (Coleoptera: Curculionidae)." Florida Entomologist 68: 370-379. 